E ISSN : $2252-4797$

Volume 9 - No. 22020

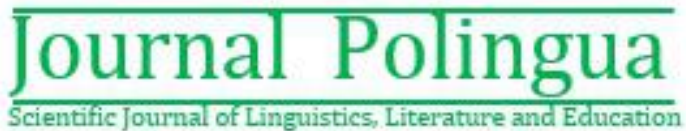

\title{
Poetry Musicalization as Desire Manifestation of Ari-Reda Group in Sapardi Djoko Damono's Poems
}

\author{
Arie Azhari Nasution ${ }^{1}$, Ricky Yudhistira Nasution², Evi Marlina Harahap ${ }^{3}$ \\ ${ }^{1}$ Fakultas Ilmu Budaya, Universitas Sumatera Utara, Medan, Indonesia \\ E-mail:1 arieazharinst@gmail.com \\ ${ }^{2,3}$ Fakultas Ilmu Budaya, Universitas Gadjah Mada, Yogyakarta, Indonesia \\ E-mail: ${ }^{2}$ rickyyudhistiranst@gmail.com, ${ }^{3}$ evimarlinaharahap@gmail.com
}

\begin{abstract}
Viewed in the past 10 years, poetry musicalization had become a trend in Indonesia. Many groups change a written poem into musical. Not only creating musical poetry, this group also utilizes technological developments to publish it. The publication is done by uploading poetry musicalisation to social media so that it can be listened by public. One of the groups best known for the music he created is the Ari-Reda group, which from the beginning focused on the poems of Sapardi Djoko Damono. Of course, many things can be highlighted when looking at the process of reproduction of a work. One of them expressed a desire as an effort to fulfill themselves. Ari-Reda in this case, expressed desire through the poem "Aku Ingint" by Sapardi Djoko Damono. The results show that Ari-Reda's desire to the poems as a fulfillment of desires between humans and humans and humans with love that is never finished because it never having time to say the desire.
\end{abstract}

Keywords — Psychoanalysis Lacanian; Ari-Reda; Desire; Poetry; Musicalization

\section{INTRODUCTION}

Technological developments in the 21 st century have a major impact on the birth of new cultures. The culture can include new ways of production, publication, reception, and so on. For example in the literary world: currently literary works utilize electronic media as a place for publication and an expression of meaning. The media can be platforms in cyberspace such as Facebook, Instagram, Twitter and Youtube. This phenomenon of production and publication can not only be seen as cyber literature, but also the transformation of literature forms. For example, on videobased platforms such as YouTube, we will find a lot of literature works such like poetry musicalization. As a result of technological developments, poetry as a literary work could be transformed into video with sound and music. It also very easy to be accessed while connected to an internet connection.

The musicalization of poetry itself offers literary consuming societies to find new alternatives that go beyond the textual nature of literature. In other words, it is not only limited to just reading to be able to enjoy it, but also to enjoy it by listening to music arrangements and poetry itself as the lyrics. Of course, it is not only how technological developments affect the literary production, but also how literary works themselves are consumed by the public and to the point of reproduction in different forms.

The poetry transformation into musical can be accessed through a video-based platform, Youtube. There are a lot of poetry musicalization can be found on the platform that takes the poems from Gunawan Moehammad, Rendra, Chairil Anwar, Sapardi Djoko Damono and so on. The persons who done this started from school students, scholar who are members of arts organizations and literary communities, and even well-known artists in Indonesia such as Reda Gaudiamo along with his colleague Ari Malibu, also participated in this phenomenon.

Ari-Reda group have released their own poetry musicalization album, including: Hujan Bulan Juni (Rain in June) (1989), Hujan Dalam Komposisi (Rain in Composition) (1996), Gadi Kecil (Little Girl) (2005), etc. The albums contained special poems by Sapardi Djoko Damono. Although it has been arranged since the $80 \mathrm{~s}$, but since the development of technology, all the new albums can be accessed easily through the YouTube platform to be heard.

Based on this phenomenon, the concern is the inseparability of the name Sapardi Djoko Damono as a writer whose works always be the choice to be transformed into musicals. In particular, Reda and his colleagues have even released a special album on Sapardi's poems. In Reda's 
narrative, she said that Sapardi who made them (Reda and Ari) cannot be separated from poetry. In addition to those mentioned above, based on searches on the YouTube platform from many of Sapardi Djoko Damono's works, there will be found the poem "Aku Ingin" (I want) which is the most sought after and transformed into musical. Hence, this article will focus on the poem "Aku Ingin" (I Want) by Sapardi Djoko Damono as the material object. The formal object of this paper is the author's desire and the Arie-Reda Group's desire on that poem based on the Lacanian perspective in psychoanalysis. The purpose of this article is to know what kind of desires to be conveyed by Sapardi through his poem and to seek the desire manifestation of Ari-Reda group who transform Sapardi's poems into musicalization. Thus, people would know the desire of Sapardi Djoko Damono as writer and the desire of Ari-Reda Group on the poem.

\section{METHOD}

This article used a qualitative method. Data collection in this study including : 1) listening intensively and repeatedly the data; 2) selecting data; 3) recording data wich is considered relevant; 4) conducting data analysis in accordance with the theory; 5) compiling research reports.

Data analysis in this study was carried out by the Lacanian Psychoanalysis method, which assumes that desires originate from unconscious processes that are structured such as language through the mechanism of metaphor and metonymy. Thus to identify the subject's desires in the poem Aku Ingin (I Want), the analysis is done by 1) identifying language (poetry text) as a manifestation of the subject's desires in the form of a series of signs (metonymy and metaphor). 2) the meaning of the signs based on the metaphor and metonymy mechanism; 3) analyze the relationship between those signs. After knowing the hidden relationships and meanings in the text of the poem, it will be seen in relation to the desires of the subject.

\section{RESUlts AND DISCUSSION}

\section{A. Lacanian Psychoanalysis Perspective}

Literary work is one manifestation of human desire. In other words, the author produces literary works as a form of fulfillment of his desires. Desire has existed in humans since he was born. Humans have desires because humans always feel inadequate or incomplete. According to Lacan, humans are always in a state of lack, and only the desire that can fill lackness.

Desire arises when the fulfillment of needs is unsatisfactory, when disturbances or gaps arise that cannot be closed. Desire arises from dissatisfaction and pushes to bring up other requests. Humans as subjects are considered deficient because they believed to be fragments of something larger and primordial [1]. So, in this case, the author is referred as a subject that lacks. From the written work, various life problems are poured to produce a certain meaning to the reader as a form of disclosure of something as well as a form of searching for identity and meeting the needs of his desires.
According to Lacan, human subjects would not exist without language. Both have a circular relationship (not reciprocal) in which language occupies a special position [1]. Through this connection, language is used by human as subjects, including an author who seeks to express everything that flares up in his soul, by, for example, writing literary works. In writing this literary work an author uses language, presents characters who interact with each other and unconsciously bring their mental problems. It is from this psychiatric problem that the study of psychoanalysis is closely related to the text.

Lacanian psychoanalysis is based on two outlines of thought namely phenomenology and structuralism. Phenomonology emphasizes free selfconcept; then structuralism emphasizes language determinism [2]. With this basis Lacan psychoanalysis focuses on the concept of self as a subject, and uses a pattern of structuralism as a way of discussion. In Lacan's view, it is unconsciousness that will govern all human existence, which is also structured like language. He based this view on Freud's description of two main mechanisms of various processes of unconsciousness, condensation, and transfer. In essence, these two mechanisms are linguistic phenomena, where meaning is condensed (in metaphors) or transferred (in metonomia). Lacan said that the content of the unconscious is fully aware of the language, and specifically consists of the structure of language [1]. Lacan also said that unconscious structures such as language mean that unconsciousness consists of signs [3].

Lacan use language as a signs. Language is a precondition for the act of being aware of oneself as an entity that is different from the others [4]. For this reason, Lacan believes that psychoanalysis must be able to become linguistics and signs because of its nature which exclusively uses language in its analysis. Lacan explains that unconsciousness occupies an important position in the subject of psychoanalysis. According to him, complete unconsciousness is aware of language, and specifically it consists of the structure of language. Unconsciousness forms same as with language. That is why Lacan's psychoanalysis can be used in analyzing literary works [2].

According to Lacan language as a disclosure system is never able to fully describe the concepts that are expressed. In this case, Lacan sees a link between psychoanalysis and linguistics. For Lacan, the unconscious is proportional to the structure of a language. This happens because formations in the unconscious and language are governed by the same mechanism as language, called metaphors and metonymy [4]. Based on the explanation, it can be said that Lacan's theory combines metaphorical ideas by considering deviations as aspects of human reality itself. Metaphors connect the subject to actual events. This deviation of meaning uses metaphors and metonymy as a mean of delivering messages in language. So, to understand literary works is to look at the language of literary works through the phenomena of metaphor and metonymy.

According to the Lacanian language concept, a marker sign always denotes another sign; there is no word that is free from metaphoricity. In other words, metaphor is a sign that signifies other sign [1]. In this case, Lacan talks about glissement in the link chain, from one sign to 
another. Language is always unable to explain a whole meaning, because language can be interpreted with various meanings.

Lacan called the language as a sign. A sign can be understood and explained in other words, so language is a series of signs that is never finish. Thus, language is always open, it opens itself up to other possible meanings. Metaphor is understood as the principle of condensation in the sense that there is an alignment of the signs and resulting a shift meaning, whereas metonymy works with the principle of "slippering" or vision that serves to distract the censor's attention [4].

Lacan divides several phases of the stages of human development according to the development of language. As Sarup explains, Lacan understands Oedipus in terms of language, not in terms of the body, and that there was no body before language existed. These phases are "real" (nature before language), "imaginary" (fantasy / imagination or nature when language has not yet been arranged), and "symbolic" (nature when language already exists and ordered). The symbolic phase is the phase in which the subject has been "installed" properly in the cultural symbolic domain, where the subject has obtained the title of Oedipus (adult subject). The trajectory of these phases by Lacan is reconciled with the concepts of need, demand, and desire [1].

The "real" phase is a reality that can never be known [1]. At this stage, a baby does not have separation from his mother. At this stage the baby does not feel lack and loss. Baby and mother are one unit and there are only needs, so it is called the concept of need. In this stage, there is only fullness and completeness where there are no unmet needs, all needs are fulfilled well because the needs are physiological. Then there is no absence, loss, or lack. So, language is not needed.

In the "imaginary" phase, a mirror phase occurs. The mirror phase in the imaginary structure is the phase in which the process of self-identification occurs. A baby is able to distinguish himself from objects around but has not been able to distinguish other objects. In the mirror phase when the baby realizes its separation from the mother. Imaginary structure is the pre-oedipal world. The self wants to unite with what he perceives as the Other [1]. The impulse that arises in this imaginary phase is called by Lacan, demand. If needs are always fulfilled, then demand is an impuls that cannot be fulfilled. When a baby looks in the mirror, the baby considers himself in the mirror to be himself, even though it is only his reflection. This makes the baby feel lost, lack, and want to reunite with his mother. The baby begin to realize that in fact there are "others" (mother and others) are intact. However, the baby still does not have the concept of "self" because the baby misinterprets and because of that, he also misidentifies himself (misrecognition). This brings the baby to the next important thing, the shifting of the concept of need to demand.

At this mirror stage, the baby identifies himself as an image in the mirror. Encouragement in children who perceive that the image in the mirror is himself is his desire to have an identity. This desire refers to the wholeness of self that drives humans to meet the needs of having a complete self. Lacan used the term Phallus as an attribute of power, both male and female. Here, the Phallus refers to the fullness; is a sign of wholeness that we do not have [1].

In the symbolic phase, the baby able to make distinctions and projections of ideas about otherness. In this phase, the baby should feel the castration (separation) with his mother and be exacerbated by the entry of the father as a symbolic other. At the same time, language acquisition took place. Symbolic is the existence of "I" in the structure of language. The situation in which "I" expressed through language. Lacan sees the language as an order that different from an imaginary order. He called it the Symbolic order, a domain where social meanings, logic, and differentiation, the order through which children begin to represent desire and grow as subjects. In short, after an imaginary subject, a symbolic subject comes [2].

These concepts for Lacan work on language, which in this analysis is to find the desires that are manifested in language. Individuals tend not to be able to distinguish the mixture between their own desires and the desires of others. Desire to have an identity drives the ego to believe itself as an object. This belief makes someone see as the desires of others, make the desire of himself with the same desires [2].

Desire is what the demand cannot specify. A demand is an expressing desires, though not directly. Desire is desire for others, which must be interpreted [1]. Adian concludes that the nature of desire are, first, desire is something that goes beyond biology, it works when biological deficiencies are fulfilled. Second, far from the domination of the ego cogito, it is a condition that allows the formation of the ego itself. Third, desire is driven by human nature as an existentially deprived creature [2]. Furthermore, this existential deficiency triggers two types of desires. First, is the desire to have (identity). This desire works in the realm of Imaginary and Symbolic experience, the realm of experience which gives a sense of wholeness to the primordial deficiencies that always overshadow the subject. The desire to have culminates in symbolization. Second, the desire to become one who works in the realm of real, pre-ideological and non-meaningful experience. The desire to become ends in symbolization. In other words, desire relates to the three domains or orders called Lacan with Real, Imaginary and Symbolic.

\section{B. Desire in Sapardi Djoko Damono's Poem}

\section{Aku Ingin (I Want)}

aku ingin mencintaimu dengan sederhana: (I want to love you with simple)

dengan kata yang tak sempat diucapkan kayu (with word that was not spoken by wood)

kepada api yang menjadikannya abu (to the fire that made it ashes)

aku ingin mencintaimu dengan sederhana: (I want to love you with simple))

dengan isyarat yang tak sempat disampaikan (with a signal that was not be conveyed) 
awan kepada hujan yang menjadikannya tiada (by cloud to the rain that made it gone)

(1989) [5]

It has been seen from the title that this poem has a desire for something that is not in self, a fulfillment of self that was not previously owned by the subject "I". "I Want" is an unfinished sentence which means that there must be a resolution of the subject's desires for what he desires as selffulfillment of the shortcomings and yearning for unity.

In the first and third sentences as a repetition of the sentence in this poem, I want to love you simply: show that "I" does not stand alone, but there is "you" as an object that "I" desired to be able to "love". It appears here that "I" and "you" are not in a relationship, because "I" is a subject who wants "you" in terms of "love" while "you" does not provide any response so that "I" will still exist even without the response from the "you".

Meanwhile, the existence of the word "simple" as metonymy which means not excessive or can be said to not have high enough expectations, making what the subject "I" wants to eliminate "you" in his presence to "love" "I". However, "I" still hope-by putting a colon (:) at the end of the sentence which can mean the desire of simple love from "I" to "you". Thus, the sentence in the next line is a continuation of the "simple" statement referred to by the subject "I".

In the second line of this poem, with word that was not spoken ... / ... with a signal that was not be conveyed, the relationship between "I" and his "simple" love shows a relationship that cannot be directly spoken or conveyed so that the position of "I" seem ambiguous. On the one hand "I" feel the love, but on the other hand, "I" do not express his feelings. In the second line of this poem explains that "I" chose not to "say" or indeed it was "no time" to say. This is the mirror phase mentioned by Lacan which is the phase of the process of self-identification and the desire to have an identity. In the mirror phase, when the baby realizes its separation from the mother and wants to reunite, but that desire cannot be fulfilled so he feels a lack. This desire refers to the wholeness of self that drives humans to meet the needs of having a complete self.

This poem appears as the surrender of "I" in reaching his desire: love. The ambiguity of what "I" feel in this poem (loving but not or not being said) is a great and painful loss but makes "I" stronger to accept that there is nothing that he gets from his love, by wood to the fire that made it ashes. The acceptance of this conditions shown in this poem seems to illustrate that this is the fulfillment of the desires of the subject "I" to be showed.

Furthermore, the word "simple" implies that between "I", and "you" and "loving" there is an ambiguity, that is, wanting to love and be loved but not being spoken or not being conveyed. Between the desire to get and the desire to let go of love out of himself.

Metaphorically, this poem likens man and his love to wood and fire, clouds and rain. If it brought into the public discourse, of course the relationship between wood and fire is a related matter. Fire is used to burn wood while wood is there to light a fire and make it grow bigger or lighter. Likewise clouds and rain. Rain exists because of the clouds and rain is coming from the clouds. The rain falling in the form of water and evaporates into clouds again. So, there is a causal relationship between them. So, the description of this poem reveals that this poem is a desire for self-fulfillment from its lacks, by releasing and surrendering his love as a result of what "cannot be conveyed". However, this also causes the subject "I" never fully to self-fulfillment and feel lack because his love for "you" becoming "ashes" and "gone" as a love relationship that does not get a response.

Metonymically, this poem replaces itself with objects and substances that can be closely related to each other (wood, fire, clouds, rain, ash). Replace the mirror "I" with "you" who is loved but "never conveyed". And what "I" wants is not a union of love but pain or destruction of love itself. With this diversion, the poem suggests that the subject in this poem is the subject that not trying to get what he wants even if it is simple: love. Thus, his desire to achieve the wholeness will be "gone".

\section{Fulfillment of Ari-Reda's Desire through Poetry Musicalization in Sapardi Djoko Damono Poems}

Viewed in the past 10 years, poetry musicalization has become a trend in Indonesia. There are so many groups that made poetry musicalization with poems from Indonesian writers. Not only create musicalization, these group also uploads the product to social media so everyone can listen to poetry musicalization for free. One of the groups best known for the music they created is the Ari-Reda group, which from the beginning focused on Sapardi Djoko Damono's poems.

It can be said that the musicalization done by Ari-Reda to Sapardi Djoko Damono's poems is a success effort because when we see on the internet, especially Youtube, the musicalization performed on Sapardi Djoko Damono's poems has a large audience: reaching 204 thousand in poetry "Aku Ingin" (I Want) [6], and 102 thousand viewers in the live video [7]. Thus, Ari-Reda became famous for singing Sapardi Djoko Damono's poem.

In the previous discussion, it was stated that the poems of Sapardi Djoko Damono describe the relationship between humans and love as a causal relationship between the two which is a fulfillment of self. Even so, the relationship between humans and their love does not always work well and smoothly so that metonymically humans often experience pain or destruction due to love itself.

In the sophisticated technology era as it is now, people tend to distract from something that make them feel "sick" and "broken" both because of other people and because of love. The distraction done by viewing and accessing social media using devices and the internet. Society, especially in Indonesia, also likes to access the contents of songs with the theme of man and his love. Therefore, the desires of the subject contained in the poem "Aku Ingin" (I Want) by Sapardi Djoko Damono can fulfill the desires of the audience because they have the same desires. In this case, the Ari-Reda group took a moment where people's desires, poetry and musical arrangements of poetry they arranged experienced in common. Likewise, the group that chose Sapardi Djoko Damono's poems as a manifestation of the 
fulfillment of their desires both to describe social relations, humans with humans and humans with love.

Thus, the transfer of printed literature into cyber literature, in this case the poetry musicalization and uploaded it to YouTube social media, is a fulfillment of the desire of the Ari-Reda group for the never ending relationship between humans and humans and humans with their love. This desire is expressed in the poems of Sapardi Djoko Damono chosen by the Ari-Reda group in manifesting their desires to be addressed to audiences who have the same lack of desire.

\section{CONCLUSIONS}

Based on psychoanalysis of the poem and Ari-Reda group above, it can be concluded that the subject experiencing lacks thus manifesting their desires through literary works with the aim of achieving wholeness. From the relationship between the signs in the poem "Aku Ingin" (I Want), metaphorically this poem likens man and his love as wood and fire, clouds and rain that have a causal relationship between the two so that with the depiction of these things in this poem is a desire for the fullness of the subject as well bring it to the self that is never intact to fulfillment of self and because of his love for "you" make it "ash" and "gone" as love relationship that does not get a response.

Metonymically, with the language replacing itself with the objects and substances (wood, fire, clouds, rain, ash) which is a mirror between "I" and "you" who are loved but "conveyed/delivered" so what the subject wants is not a union of love but pain or destruction of love itself. With this diversion, the poem suggests that the subject in this poem is the subject not trying to get what he wants and love.

Likewise, the Ari-Reda group chose the poems of Sapardi Djoko Damono to be used as a musical arrangement of poetry and uploaded to social media Youtube which can be identified as cyber literature. The change from print literature to cyber literature by the Ari-Reda group is a manifestation of the fulfillment of desires between humans and humans and humans with their love that never finished. This desire was found by Ari-Reda in Sapardi Djoko Damono's poems as a fulfillment of their desire for love.

\section{REFERENCES}

[1] Sarup, M. 2011. Postrukturalisme dan Posmodernisme diterjemahkan oleh Medhy Aginta dari judul An Introdutory Guide to Post-Structuralism and Posmodernism. Second printed. Yogyakarta: Jalasutra.

[2] Bracher, M. 2009. Jacques Lacan: Diskursus, dan Perubahan Sosial: Pengantar Kritik-Budaya Psikoanalisis. Yogyakarta: Jalasutra.

[3] Chiesa, Lorenzo. 2007. Subjectivity And Otherness A Philosophical Reading Of Lacan. Massachusetts: Mit Press.

[4] Faruk, 2012. Metode Penelitian Sastra. Cetakan ke-1. Yogyakarta: Pustaka Pelajar.

[5] Damono, Sapardi Djoko, 1994, Hujan Bulan Juni, Jakarta: PT. Grasindo.

[6] Art, Bad. 2017. Ari Reda - Aku Ingin Lirik video. Accessed on 30 Juni 2020, via https://www.youtube.com/watch?v=8ppoCaHXhnk.

[7] Lahandoe, Han. 2017. Ari Reda - Aku Ingin - Sapardi Djoko Damono [live]. Accessed 30 Juni 2020, via https://www.youtube.com/watch?v=Rf9FxL6KvE4. 